\title{
Antisnake venom activity and isolation of quercetin from the leaf of Neocarya macrophylla (Sabine) Prance ex F. White (Malpighiales: Chrysobalanaceae)
}

\author{
A. J. Yusuf ${ }^{1}$, , M. I. Abdullahi ${ }^{1}$, A. M. Musa ${ }^{2}$, A. K. Haruna ${ }^{2}$, \\ V. Mzozoyana ${ }^{3}$ and H. Abubakar ${ }^{4}$
}

${ }^{1}$ Department of Pharmaceutical and Medicinal Chemistry. Usmanu Danfodiyo University. Sokoto. Nigeria. *Email: amynajega@gmail.com.

${ }^{2}$ Department of Pharmaceutical and Medicinal Chemistry. Ahmadu Bello University. Zaria. Nigeria.

${ }^{3}$ School of Chemistry and Physics. University of KwaZulu-Natal. Westville. Durban. South Africa.

${ }^{4}$ Department of Chemistry. Sokoto State University. Sokoto. Nigeria.

\begin{abstract}
Snake envenomation is a major cause of death and disability in many developing countries. Neocarya macrophylla (Sabine) Prance ex F. White (Malpighiales: Chrysobalanaceae) have been reportedly used in traditional medicine to treat snake envenomation. Bioassay-guided isolation of antivenom principles was carried out on the leaf of $N$. macrophylla against Naja nigricollis venom. The methanol extract of $N$. macrophylla leaf and its ethylacetate and $n$-butanol fraction significantly $(\mathrm{P}<0.05)$ protected mice against venom-induced lethality with $100 \%$ survival rate and there was remarkable inhibition of the poisonous effects of $\mathrm{PLA}_{2}$ enzyme by the extracts and the fractions. Encouraged by this result, the ethylacetate soluble fraction was subjected to purification using vacuum liquid chromatography and gel filtration which led to the isolation of quercetin as the bioactive principle. The identity of the compound was determined on the basis of chemical tests, and by comparison of its ${ }^{1} \mathrm{H}-\mathrm{NMR}$ data with literature, this is the first report of isolation of this compound from the leaf of the plant. However, the results of the study suggests that the leaf of N. macrophylla possess significant antisnake venom activity which provide the scientific basis for its use in traditional treatment of snakebites.
\end{abstract}

Keywords: Neocarya macrophylla; Leaf; Antivenom; Quercetin; NMR.
Received

April 20, 2019

Accepted

August 28, 2019

Available online

August 29, 2019

Released

August 31, 2019

Full Text Article

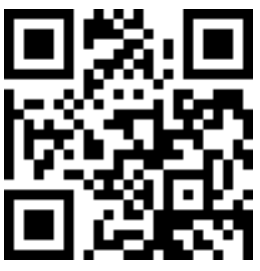

ORCID

DD 0000-0002-4557-859X A. J. Yusuf

() 0000-0002-9049-9057 M. I. Abdullahi

๑ $00000-0001-7985-9157$ A. M. Musa 


\section{Introduction}

Snakebites is a neglected public health concern in many developing countries (Alirol et al., 2010; Chippaux, 2011) especially in the rural areas where access to healthcare facilities is severely limited (Aleku et al., 2014; Dechambenoit, 2016). Consequently, many snakebite patients rely on alternative herbal medicinal antivenom products with no or limited scientific evidence of safety and efficacy.

Ginger bread plum Neocarya macrophylla (Sabine) Prance ex F. White (Malpighiales: Chrysobalanaceae) has been used folklorically in Northern Nigeria to treat several diseases, including infectious diseases and snake bites (Yusuf et al., 2015a). Previous phytochemical investigations of other members of the Chrysobalanaceae Family have been adequately documented. Chemotaxonomically, flavonoids, steroids and terpenes are the major constituents of the plant family (Carnevale Neto et al., 2013). The ease of availability of this plant in Nigeria and elsewhere prompted us to conduct antisnake venom activity and phytochemical analysis of the stem bark of $N$. macrophylla in which stigmasterol and bis-(5,7-diacetyl-catechin-4'- $\alpha$ rhamnopyranoside) were isolated (Yusuf et al., 2015a; Yusuf et al., 2015b). Indeed, we have recently demonstrated the antimicrobial activity of stigmasterol isolated from $N$. macrophylla, exhibiting broad spectrum antimicrobial activity thereby validating its use for the treatment of infectious diseases (Yusuf et al., 2018).

The correlation of the anecdotal use and observed biological activity of the stem-bark of $N$. macrophylla strengthen us to provide scientific basis for the use of the leaf of the plant in the treatment of snakebites. We report herein, the antisnake venom activity of the methanol leaf extract of $N$. macrophylla and against Naja nigricollis venom and isolation of quercetin, a known flavonoid. Fractionation of the $\mathrm{MeOH}$ leaf extract and the subsequent purification of a promising bioactive fraction (EtOAc soluble fraction) led to the isolation and structure elucidation of a bioactive principle, quercetin.

\section{Methodology}

NMR data were recorded on a Bruker AVANCE spectrometer $(600 \mathrm{MHz})$ with residual solvent as internal standard. Melting point was determined on an Electro thermal melting point apparatus. Thin layer chromatography (TLC) was carried out using silica gel 60 $\mathrm{GF}_{254}$ pre-coated aluminium sheets by Sigma Aldrich, Germany. Vacuum liquid chromatography was conducted using LOBA Cheme silica gel (60-200) mesh in a sintered glass funnel while gel filtration chromatography was performed using sephadex LH-20 (Sima, Spruce Street, St. Louis, MO, USA). Spots on TLC plates were visualized by spraying with $10 \%$ $\mathrm{H}_{2} \mathrm{SO}_{4}$ followed by heating at $105{ }^{\circ} \mathrm{C}$ for $10 \mathrm{~min}$.

\section{Plant sample}

The plant sample of N. macrophylla was collected in October, 2015 at Jega Local Government Area of Kebbi State. It was identified by Namadi Sanusi at the Herbarium Unit, Department of Biological Sciences, Ahmadu Bello University by comparing 
with herbarium reference voucher specimen (No. 3197). The leaf was shade dried, pulverized to powder, labelled and stored at room temperature for use.

\section{Experimental animals}

Swiss albino mice of either sex weighing (18-24 g) were obtained from the Animal House Facility of the Department of Pharmacology and Therapeutics, Ahmadu Bello University, Zaria, Nigeria. They were fed with laboratory diet and water ad libitum and maintained under standard conditions (12 $\mathrm{h}$ light and $12 \mathrm{~h}$ dark cycle) in propylene cages at room temperature. All experimental procedures were approved by the Animal Right and Ethics Committee of the University.

\section{Snake venom}

The venom of an adult $N$. nigricollis was collected by the milking method of Macfarlane (1967). It was pooled, lyophilized and stored at $4{ }^{\circ} \mathrm{C}$ until required. The venom was subsequently referred to as the crude venom of $N$. nigricollis.

\section{Antisnake venom}

Lyophilized polyvalent snake venom antiserum sourced from VINS Nioproduct Limited, Andra Pradesh, India (Batch. number: 01AS14054, Manufacturing Date: July 2015, Expiry date: June 2018) was used for the study.

\section{Preparation of plant material}

The leaf of $N$. macrophylla $(1.9$ $\mathrm{kg}$ ) was exhaustively extracted with 90 $\% \mathrm{MeOH}$ and the combined extracts were evaporated in vacuo to dryness to afford $\mathrm{MeOH}$ leaf extract (288 g). Some part (200 g) of the extract was suspended in distilled water and successively partitioned into $n$-hexane, chloroform, EtOAc and $n$-butanol fractions.

\section{$\mathbf{L D}_{50}$ determination}

The intraperitoneal $\mathrm{LD}_{50}$ of the $\mathrm{MeOH}$ leaf extract and its fractions (EtOAc and $n$-butanol) was determined according to the method described by Lorke (1983).

\section{Lethality assay of the venom}

The $\mathrm{LD}_{99}$ of the venom was determined by the method described by Theakston and Reid (1983) and the LD99 value was calculated by probit analysis (Finney, 1977) of death occurring within $24 \mathrm{~h}$ of venom injection.

\section{In vivo detoxifying effect}

The method described by Theakston and Reid (1983) was employed. Twenty mice (20) were divided into five groups $(n=4)$. Group 1 (control) received $1 \mathrm{~mL} / \mathrm{kg}$ of saline. Groups 2, 3 and 4 (test groups) received 20,40 and $80 \mathrm{mg} / \mathrm{kg}$ of the $\mathrm{MeOH}$ leaf extract, respectively. The groups were then injected with MLD (LD $99,5.75$ $\mathrm{mg} / \mathrm{kg}$ ) of the reconstituted venom 30 min after injecting the extract. The route of administration was intraperitoneal (i.p.). All animals were observed for mortality for $24 \mathrm{~h}$. The experiment was repeated for the EtOAc (20, 40 and 80 $\mathrm{mg} / \mathrm{kg}$ ) and $n$-butanol 5, 10 and 20 $\mathrm{mg} / \mathrm{kg}$ ) fractions.

\section{In vitro detoxifying effect}

The method described by Abubakar et al. (2000) was employed in this study. Twenty (20) mice were divided into four groups $(n=5)$. Group 1 (control) received the MLD (LD99, 5.75 $\mathrm{mg} / \mathrm{kg}$ ) of $N$. nigricollis venom only. Groups 2, 3 and 4 (treatment groups) received an equivalent of the MLD of the venom which was previously incubated at $37{ }^{\circ} \mathrm{C}$ for $10 \mathrm{~min}$ with 20,40 and 80 $\mathrm{mg} / \mathrm{kg}$ of the $\mathrm{MeOH}$ leaf extract and the animals were observed for mortality for $24 \mathrm{~h}$. The route of administration was intraperitoneal. The experiment was repeated for the EtOAc (20, 40 and 80 $\mathrm{mg} / \mathrm{kg}$ ) and $n$-butanol 5,10 and 20 $\mathrm{mg} / \mathrm{kg}$ ) fractions.

\section{Phospholipase $A_{2}\left(P_{2} A_{2}\right)$ assay}

The method of Tan and Tan (1988) was used to conduct the study. 
Equal volumes of substrate comprising calcium chloride (18 $\mathrm{mM})$, sodium deoxycholate $(8.1 \mathrm{mM})$ and egg yolk were mixed and stirred for $10 \mathrm{~min}$ to get homogenous egg yolk suspension. The $\mathrm{pH}$ of the suspension was adjusted to 8.0 by addition of sodium hydroxide (1 M). Snake venom $(0.3 \mathrm{mg} / \mathrm{mL})$ was added to the above mixture $(15 \mathrm{~mL})$ to initiate the process of hydrolysis and saline was used as control. Decrease in $\mathrm{pH}$ of the suspension was noted after two minutes with the help of a $\mathrm{pH}$ meter. A decline in $1.0 \mathrm{pH}$ unit corresponds to $133 \mu$ moles of fatty acid released in the egg yolk mixture. The enzymatic activity of phospholipase $\mathrm{A}_{2}$ was calculated from the data obtained as micromoles of fatty acid released per minute (Tan and Tan, 1988).

To test the antisnake venom potential of $N$. macrophylla, snake venom (0.1 mg) was pre-incubated with the $\mathrm{MeOH}$ extract of the plant and its fractions $(0.5 \mathrm{mg} / \mathrm{mL})$ to neutralize the hydrolytic action of $\mathrm{PLA}_{2}$. Protection offered by the $\mathrm{MeOH}$ leaf extract, EtOAc and $n$-butanol fractions against the phospholipases.

\section{Isolation of compound}

The EtOAc fraction was chromatographed on silica gel vacuum liquid chromatography using $n$-hexane: EtOAc mixtures as solvent system. Thirty $(30 \mathrm{~mL})$ each of a total of 80 fractions were collected and merged based on their TLC profile to afford seven (7) major fractions E1 - E7. Further purification of fraction E2 using sephadex LH-20 afforded a yellow solid substance (Compound 1). It was subjected to chemical test and spectroscopic analysis to elucidate its chemical structure.

\section{Spectral data}

Quercetin (7 mg). Yellow solid substance; m.p 310-312 $37{ }^{\circ} \mathrm{C} .{ }^{1} \mathrm{H}-\mathrm{NMR}$ $\left(\mathrm{CD}_{3} \mathrm{OD}, 600 \mathrm{MHz}\right): \delta_{H} 7.76(1 \mathrm{H}, \mathrm{d}, J=2.2$ $\left.\mathrm{Hz}, \mathrm{H}-2^{\prime}\right), 6.92\left(1 \mathrm{H}, \mathrm{d}, J=8.4 \mathrm{~Hz}, \mathrm{H}-5^{\prime}\right)$, $7.67\left(1 \mathrm{H}, \mathrm{dd}, J=2.2,8.4 \mathrm{~Hz}, \mathrm{H}-6^{\prime}\right), 6.42$
(1H, d, J=2.2 Hz, H-6), 6.22 (1H, d, J=2.2 $\mathrm{Hz}, \mathrm{H}-8)$.

\section{Results and discussion}

N. macrophylla has been used in ethnomedicine to treat snakebite victims (Yusuf et al., 2015a); this study was performed to establish any scientific evidences justifying its use for this purpose. First, acute toxicity profile of methanolic extract and the resulting fractions was investigated. The median lethal dose $\mathrm{LD}_{50}$ of the $\mathrm{MeOH}$ leaf extract was found to be $288 \mathrm{mg} / \mathrm{kg}$; values of 565 and $141 \mathrm{mg} / \mathrm{kg}$ were obtained for EtOAc fraction and $n$-butanol fractions indicating that the extract and its fractions are toxic (Lorke, 1983); Similar value was reported for the $\mathrm{MeOH}$ stem bark extract of the plant (Yusuf et al., 2015a). The MLD (LD99) of the $N$. nigricollis venom estimated by probit analysis was $5.75 \mathrm{mg} / \mathrm{kg}$. Although, Ode and Asuzu (2006) reported a value (6 $\mathrm{mg} / \mathrm{kg}$ ) for the same species of snake. However, higher values $(9.55 \mathrm{mg} / \mathrm{kg})$ and $(9.7 \mathrm{mg} / \mathrm{kg})$ were reported by Abubakar et al. (2000) and Isah et al. (2015) respectively. This variability observed in the minimum lethal doses of the venom might be due to the difference in venom composition which is attributed to geographic location, subspecies, season, age and diet of the snakes (Chippaux et al., 1991; Daltry et al., 1996).

In vivo antivenom activity was observed for the $\mathrm{MeOH}$ leaf extract. There was $20 \%$ protection at 20 and 40 $\mathrm{mg} / \mathrm{kg}$; no protection was observed at the highest dose $(80 \mathrm{mg} / \mathrm{kg})$. However, activity was diminished after partitioning the extract into EtOAc and $n$-butanol fractions (Table 1). Interestingly, the $\mathrm{MeOH}$ leaf extract and its fractions (EtOAc and $n$-butanol) significantly $(P<$ $0.05)$ protected mice against venominduced actions in vitro with $100 \%$ survival rate at the graded doses employed (Table 2). This was further validated by subjecting the extract and 
fractions to phospholipase $\mathrm{A}_{2} \quad\left(\mathrm{PLA}_{2}\right)$ enzyme acidimetric assay. In this assay, $\mathrm{PLA}_{2}$ enzymes were hydrolyzed and free fatty acids were released in the presence of sodium deoxycholate. $N$. nigricollis venom was found to liberate free fatty acid which was measured in terms of decrease in $\mathrm{pH}$ of egg suspension. The $\mathrm{MeOH}$ leaf extract and its fractions were able to inhibit the hydrolytic action of $\mathrm{PLA}_{2}$ activity (Figure 1). The $\mathrm{MeOH}$ extract showed superior inhibitory effect when compared to its fractions, displaying $52.5 \%$ protection from the poisonous effect of $\mathrm{PLA}_{2}$; while the $n$ butanol and EtOAc fractions which displayed 33.3 and $31.5 \%$ inhibition, respectively.

Table 1. In vivo detoxifying effect of extract/fraction of $N$. macrophylla against $N$. nigricollis venom.

\begin{tabular}{llcccc}
\hline \multirow{2}{*}{\begin{tabular}{c} 
Treatment component \\
\cline { 3 - 5 }
\end{tabular}} & Control group LD & \multicolumn{3}{c}{$\begin{array}{c}\text { \% Survival of mice within 24 hours on } \\
\text { different treatment doses }\end{array}$} \\
\cline { 3 - 5 } & & T1 & T2 & T3 \\
\hline MEL & Extract & 0 & 20 & 20 & 0 \\
EF & Fraction & 0 & 0 & 0 & 0 \\
BF & Fraction & 0 & 0 & 0 & 0 \\
\hline
\end{tabular}

Key: $\mathrm{MEL}=$ methanol leaf extract; $\mathrm{EF}=\mathrm{e}$ thylacetate fraction; $\mathrm{BF}=n$-butanol fraction; $\mathrm{T}=$ Treatment dose. $\mathrm{T} 1=20 \mathrm{mg} / \mathrm{kg}) ; \mathrm{T} 2=40 \mathrm{mg} / \mathrm{kg} ; \mathrm{T} 3=80 \mathrm{mg} / \mathrm{kg} . P<0.05$ compared with control were considered significant (Chi-Square test); $(n=5)$.

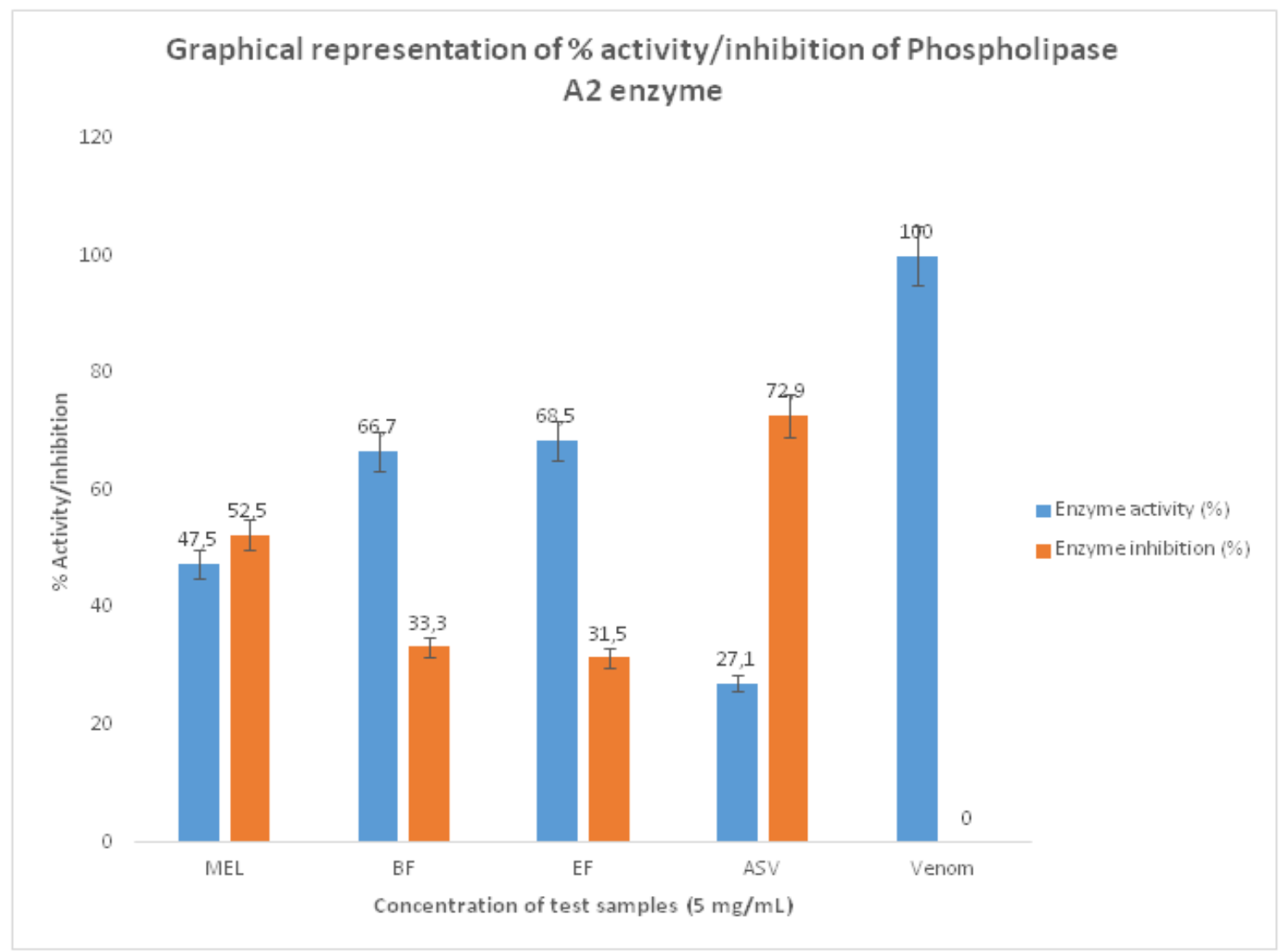

Figure 1. PLA 2 Enzyme activity and inhibition by the extract/fractions of $N$. macrophylla.

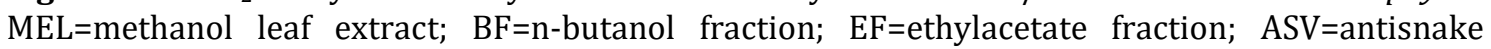
venom. 
Table 2. In vitro detoxifying effect of extract/fraction of N. macrophylla against $N$. nigricollis venom.

\begin{tabular}{llcccc}
\hline \multirow{2}{*}{ Treatment component } & \multirow{2}{*}{$\begin{array}{c}\text { Control group } \\
\text { LD99 }\end{array}$} & \multicolumn{3}{c}{$\begin{array}{c}\text { \% survival of mice within 24 h on } \\
\text { different treatment doses }\end{array}$} \\
\cline { 4 - 6 } & & & T1 & T2 & T3 \\
\hline MEL & Extract & 0 & $100^{*}$ & $100^{*}$ & $100^{*}$ \\
EF & Fraction & 0 & $100^{*}$ & $100^{*}$ & $100^{*}$ \\
BF & fraction & 0 & $100^{*}$ & $100^{*}$ & $100^{*}$ \\
\hline
\end{tabular}

$\mathrm{MEL}=$ methanol leaf extract; $\mathrm{EF}=$ ethylacetate fraction; $\mathrm{BF}=\mathrm{n}$-butanol fraction; $\mathrm{T}=$ Treatment dose. $\mathrm{T} 1(\mathrm{mg} / \mathrm{kg})=\mathrm{MEL}, \mathrm{EF}(20) ; \mathrm{T} 2(\mathrm{mg} / \mathrm{kg})=\mathrm{MEL}, \mathrm{EFL}(40) ; \mathrm{T} 3(\mathrm{mg} / \mathrm{kg})=\mathrm{MEL}, \mathrm{EF}(80) . \mathrm{T} 1(\mathrm{mg} / \mathrm{kg})=$ $\mathrm{BF}(5) ; \mathrm{T} 2(\mathrm{mg} / \mathrm{kg})=\mathrm{BF}(10) ; \mathrm{T} 3(\mathrm{mg} / \mathrm{kg})=\mathrm{BF}(20) . P<0.05$ compared with control were considered significant (Chi-Square test); $(\mathrm{n}=5)$.

Inspired by the antivenin activity of the $\mathrm{MeOH}$ extract, effort at isolating a bioactive constituent was explored. The EtOAc fraction of the $\mathrm{MeOH}$ leaf extract of $N$. macrophylla was subjected to chromatographic studies which led to the isolation of a known flavonoid. It reacted positively to Shinoda test suggesting the presence of phenolic nucleus (Silva et al., 1998). The 1H-NMR spectra of the isolated compound exhibited chemical shift values typical of flavonoids (Mabry et al., 1970; Sani et al., 2015). The presence of 1, 2, 3, 5-tetrasubstituted benzene ring $\mathrm{A}$ was revealed via the proton shifts at $\delta_{H} 6.42(1 \mathrm{H}, \mathrm{d}, \mathrm{J}=2.2 \mathrm{~Hz})$ and $\delta_{H} 6.22(1 \mathrm{H}, \mathrm{d}, \mathrm{J}=2.2 \mathrm{~Hz})$ representing H-6 and $\mathrm{H}-8$ respectively. The proton resonances at $\delta_{H} 7.76(1 \mathrm{H}, \mathrm{d}, \mathrm{J}$ $=2.2), \delta_{H} 6.92(1 \mathrm{H}, \mathrm{d}, 8.4 \mathrm{~Hz})$ and $\delta_{H} 7.67$ $(1 \mathrm{H}, \mathrm{dd}, \mathrm{J}=2.2,8.3 \mathrm{~Hz})$ indicated the presence of a 1, 3, 4-trisubstituted aromatic ring $\mathrm{B}$. The chemical shift for these protons correspond to the chemical shift values reported for Quercetin by Mabry et al. (1970) and Sani et al. (2015) (Table 3). Based on the above data and comparison with reported literature (Mabry et al., 1970), the compound was confirmed to be 3,5 , 7, 3', 4'-pentahydroxylflavonol or quercetin (Figure 2).

Table 3. ${ }^{1} \mathrm{H}-\mathrm{NMR}$ data of compound 1 compared with reported literature.

\begin{tabular}{lll}
\hline Position & 1H-NMR of compound 1 $(\mathbf{~ = ~ H z ) ~}$ & 1H-NMR (Mabry et al., 1970) \\
\hline 2 & & \\
3 & & \\
4 & & \\
5 & & $6.21(\mathrm{~d}, 1.98 \mathrm{~Hz})$ \\
6 & $6.22(\mathrm{~d}, 2.2 \mathrm{~Hz})$ & $6.42(\mathrm{~d}, 1.98 \mathrm{~Hz})$ \\
7 & & \\
8 & $6.42(\mathrm{~d}, 2.2 \mathrm{~Hz})$ & \\
9 & & $7.76(\mathrm{~d}, 2.04 \mathrm{~Hz})$ \\
10 & & \\
$1^{\prime}$ & & \\
$2^{\prime}$ & $7.76(\mathrm{~d}, 2.2 \mathrm{~Hz})$ & $6.91(\mathrm{~d}, 8.34 \mathrm{~Hz})$ \\
$3^{\prime}$ & & $7.66(\mathrm{dd}, 2.1,8.40 \mathrm{~Hz})$ \\
$4^{\prime}$ & & \\
$5^{\prime}$ & $6.92(\mathrm{~d}, 8.4 \mathrm{~Hz})$ & \\
$6^{\prime}$ & $7.67(\mathrm{dd}, 2.2,8.4 \mathrm{~Hz})$ & \\
\hline
\end{tabular}




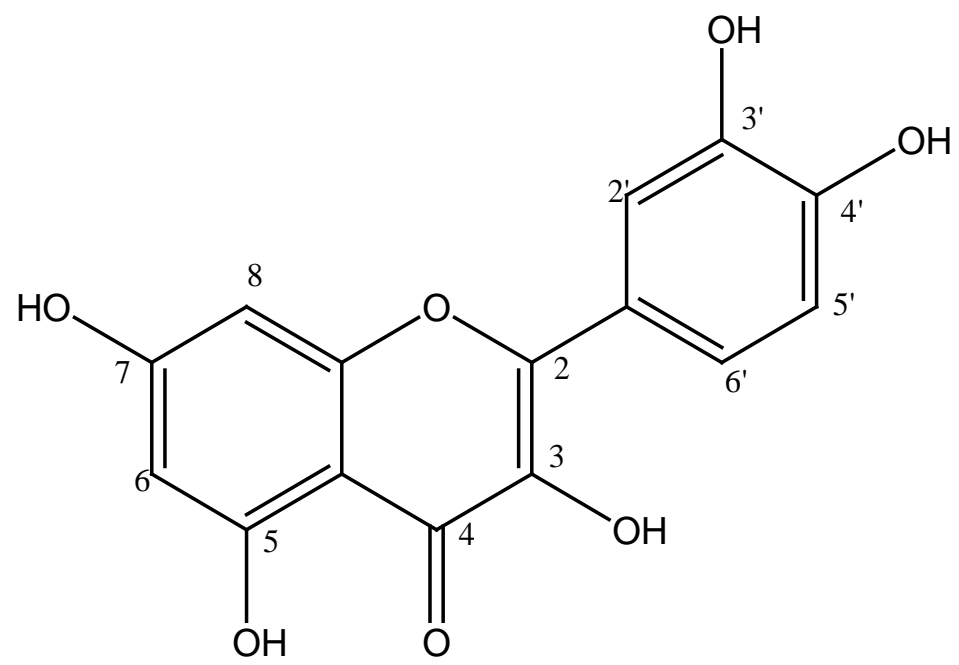

Figure 2. 3, 5, 7, 3', 4'-pentahydroxyl flavonol (quercetin).

The mechanism of action of the active constituents of plant extracts have been suggested to be associated with enzymes (Tsai et al., 1980; Bhat et al., 1991); toxic effects of snake bites are associated with enzymes (Stocker, 1990) mainly through the hydrolytic action of phospholipase $\mathrm{A}_{2} \quad\left(\mathrm{PLA}_{2}\right)$ which is thought to be the most toxic component (Mahanta and Muhkerji, 2001) implicated in tissue necrosis and haemorrhage (Melo and Ownby, 1999). The extract and fractions were observed to significantly $(\mathrm{P}<0.05)$ protect the laboratory animals against venominduced lethality in vitro. This effect might be linked to activity of the extract and fractions against the toxic enzymes (Haslam, 1989) suggesting the leaf of $N$. macrophylla might have prophylactic effect.

Most bioactive molecules isolated from medicinal plants with antiophidic activity are phenolic compounds with aromatic ring substituted by one or more hydroxyl groups (Nicholson and Hammerschmidt, 1992). However, studies have shown that hydroxyl group at position 5 , double bond and double bonded oxygen in the oxane ring are important for the overall capacity of flavonoids to inhibit $\mathrm{PLA}_{2}$ activity. In addition to that, hydroxyl groups in positions 3' and 4' are required for the selective inhibition of PLA PLI $_{2}$ (Chippaux et al., 1997; Lindahl and Tagesson, 1997). The observed antivenin activity could be linked to the presence of quercetin.

In addition, quercetin is a plant derived polyphenolic compound and have been reported to possess different biological activities including antisnake venom (Haslem, 1989), cardiovascular protection, anticancer, anti-tumor, antiinflammatory, antidiabetic, anti-ulcer, anti-viral, anti-allergy, antihypertensive, anti-infective, gastro protective and immunomodulatory effects (Alexander et al., 2016).

\section{Conclusion}

In summary, we have shown that methanolic leaf extract of $N$. macrophylla possessed antisnake venom activity. Fractionation and purification of the crude $\mathrm{MeOH}$ extract led to the isolation of a compound identified as quercetin. Although the antisnake venom activity of the isolated quercetin could not be evaluated due to paucity of the material, the flavonoid quercetin has previously been shown to exhibit different pharmacological activities including antisnake venom. Effort is ongoing in our laboratory to further isolate this 
compound in sufficient quantity to allow for detailed bioactivity profiling of quercetin and to evaluate its potential as lead in the development novel antisnake venom therapeutic agent.

\section{Acknowledgment}

Our special gratitude to Mr. Dilip Jagjivan, School of Chemistry and Physics, University of Kwa-Zulu NatalDurban, South Africa, for running the 1DNMR spectroscopy.

\section{Conflicts of interest}

Authors declare that they have no conflict of interests.

\section{References}

Abubakar, M. S.; Sule, M. I.; Pateh, U. U.; Abdulrahman, E. M.; Haruna, A. K.; Jahun, B. M. In vitro snake venom detoxifying action of the leaf extract of Guiera senegalensis. Journal of Ethnopharmacology, v. 69, no. 3, p. 253-257, 2000. https://doi.org/10.1016/ s0378-8741(99)00128-2

Aleku, G. A.; Adoga, M. P.; Agwale, S. HIV point-of-care diagnostics: Meeting the special needs of sub-Saharan Africa. The Journal of Infection in Developing Countries, v. 8, no. 10, p. 1231-1243, 2014. https://doi.org/ $10.3855 /$ jidc. 4664

Alexander, V.A. D.; Radhakrishnan, A.; Subramann, P. Overviews of biological importance of quercetin: A bioactive flavonoid. Pharmacognosy Review, v. 10, no. 20, p.84-89, 2016. https://doi.org/ 10.4103/0973-7847.194044

Alirol, E.; Sharma S. K.; Bawaskar S. H.; Kuch U.; Chappuis F. Snake bite in South Asia: A review. PLoS Neglected Tropical Diseases, v. 4, no. 1, e603, 2010. https://doi.org/ 10.1371/journal.pntd.0000603

Bhat, M. K.; Kasturi, S.; Gowda, T. V. Structure-function relationships among neurotoxic phospholipases: NN-XIII-PLA2 from Indian cobra (Naja naja naja) and VRV PL-V from Russell's viper (Vipera russelli) venoms. Toxicon, v. 29, no. 1, p. 97-105, 1991. https://doi.org/10.1016/00410101(91)90042-P
Carnevale Neto, F.; Pilon, A. C.; Bolzani, B. V.S.; Castro-Gamboa, I. Chrysobalanaceae: Secondary metabolites, ethnopharmacology and pharmacological potential. Phytochemistry Reviews, v. 12, no. 1, p. 121-146, 2013. https://doi.org/10.1007/ s11101-012-9259-z

Chippaux, J. P. Estimate of the burden of snakebites in Sub-Saharan Africa: A metaanalytic approach. Toxicon, v. 57, no. 4, p. 586-599, 2011. https://doi.org/10.1016/ j.toxicon.2010.12.022

Chippaux, J. P.; Goyffon, M. Antivenom serotherapy: Its applications, its limitations, its future. Bulletin de la Société de Pathologie Exotique, v. 84, no. 3, p. 286-297, 1991.

Chippaux, J. P.; Rakotonirina, V. S.; Rakotonirina, A.; Dzikouk, G. Drug or plant substances which antagonize venoms or potentiate antivenins. Bulletin de la Société de Pathologie Exotique, v. 90, no. 4, p. 282-285, 1997.

Daltry, J. C.; Wuster, W.; Thorpe, R. S. Diet and snake evolution. Nature, v. 379, p. 537-540, 1996. https://doi.org/10.1038/379537a0

Dechambenoit G. Access to health care in Sub-Saharan Africa. Surgical Neurology International, 7:108, 2016. https://doi.org/ 10.4103/2152-7806.196631

Finney, D. J. Probit analysis. 3. ed. Cambridge: Cambridge University Press, 1977.

Haslam, E.; Lilley, T. H.; Cai, Y.; Martin, R.; Magnolato, D. Traditional herbal medicinesthe role of polyphenols. Planta Medica, v. 55, no. 1, p. 1-8, 1989. https://doi.org/10.1055/ s-2006-961764

Isa, H. I.; Ambali, S. F.; Suleiman, M. M.; Abubakar, M. S.; Kawu, M. U.; Shittu, M.; Yusuf, P. O.; Habibu, B. In vitro neutralisation of Naja nigricollis venom by stem-bark extracts of Commiphora africana A. Rich. (Burseraceae). Journal of Environmental Science, Toxicology and Food Technology, v. 9 , no. 12 , p. $100-105,2015$.

Lindahl, M.; Tagesson, C. Flavonoids as phospholipase A2 inhibitors: Importance of their structure for selective inhibition of group II phospholipase A2. Inflammation, v. 21, no. 3, p. 347-356, 1997. https://doi.org/10.1023/a:1027306118026 
Lorke, D. A New approach to practical acute toxicity testing. Archives of Toxicology, $\begin{array}{lll}\text { v. } 54, \quad \text { no. } 4, & \text { p. 275-287, } 1983 .\end{array}$ https://doi.org/10.1007/bf01234480

Mabry, T. J.; Markham, K. R.; Thomas, Y. B. The systematic identification of flavonoids. Berlin: Springer-Verlag Publication, 1970.

Macfarlane, R. G. Russel's viper's venoms, 1963-1964. British Journal of Haematology, v. 13, p. 437-451, 1967. https://doi.org/10.1111/j.1365-2141.1967. tb00754.x

Mahanta, M.; Mukherjee, A. K. Neutralisation of lethality, myotoxicity and toxic enzymes of Naja nigricollis venom by Mimosa pudica root extracs. Journal of Ethnopharmacology, v. $75, \quad$ no. $1, \quad$ p. $55-60, \quad 2001$. https://doi.org/10.1016/s0378-8741(00) 00373-1

Melo, P.A.; Ownby, C. L. Ability of wedelolactone, heparin, and parabromophenacyl bromide to antagonize the myotoxic effects of two crotaline venoms and their PLA2 myotoxins. Toxicon, v. 37, no. 1, p. 199-215, 1999. https://doi.org/10.1016/ s0041-0101(98)00183-4

Nicholson, R. L.; Hammerschmidt, R. Phenolic compounds and their role in disease resistance. Annual Review of Phytopathology, v. 30, p. 369-389, 1992. https://doi.org/10.1146/annurev.py.30.090 192.002101

Ode, O. J.; Asuzu, I. U. The anti-snake venom activities of the Crinum jagus (Amaryllidaceae). Toxicon, v. 48, no. 3, p. 331-342, 2006. https://doi.org/10.1016/ j.toxicon.2006.06.003

Sani, Y. M.; Musa, A. M.; Abdullahi, S. M.; Nasir, T.; Abdullahi, M. I.; Atiku, I. Quercetin and $\beta$-sitosterol isolated from the methanol leaves extract of Cissus polyantha Glig and Brandt (Vitaceae). Nigerian Journal of Pharmacology Sciences, v. 14 , no. 2, p. 46-50, 2015.

Silva, G. L.; Lee I.; Douglas K. A. Special problems with extraction of plants. In:
Cannell, J. P. R. (Eds.). Natural products isolation. New Jersey, USA: Human Publishers, 1998. p. 251-293.

Stocker, K. F. Composition of snake venoms. In: Stocker, K. F. (Ed.). Medical use of snake venom proteins. Boston: CRC Press, 1990.

Tan, N. H.; Tan, C. S. Acidimetric assay of phospholipase A using egg yolk suspension as substrate. Analytical Biochemistry, v. 170, no. 2, p. 282-288, 1988. https://doi.org/10.1016/0003-2697(88) 90632-x

Theakston, R. D. G.; Reid, H. A. The development of simple standard assay procedures for characterization of snake venoms. Bulletin WHO, v. 61, p. 946-956, 1983.

Tsai, L. H.; Yang, L. L.; Chang, C. Inactivation of Formosan snake venoms in vivo by aristolochic acid the chemical components of Aristolocia radix. Tai-Wan Ko'Hsueh, v. 34, no. 2, p. 40-44, 1980.

Yusuf, A. J.; Abdullahi, M. I.; Aleku, G. A.; Ibrahim, I. A. A.; Alebiosu, C. 0.; Yahaya, M.; Adamu, H. W.; Sanusi, A.; Mailafiya, M. M.; Abubakar, H. Antimicrobial activity of stigmasterol from the stem bark of Neocarya macrophylla. Journal of Medical Plants for Economic Development, v. 2, no. 1, a38, 2018.

Yusuf, A. J.; Abdullahi, M. I.; Haruna, A. K.; Idris, A. Y.; Musa, A. M. Preliminary phytochemical screening, toxicological and antivenin property of the stem bark of Neocarya macrophylla on Naja nigricollis venom. African Journal of Pharmaceutical Research and Development, v. 7, no. 1, p. 6-10, 2015a.

Yusuf, A. J.; Abdullahi, M. I.; Haruna, A. K.; Idris, A. Y.; Musa, A. M. Isolation and characterization of stigmasterol and Bis-(5,7diacetyl-catechin-4'- $\alpha$-rhamnopyranoside) from the stem bark of Neocarya macrophylla (Sabine) Prance (Chrysobalanaceae). Nigerian Journal of Basic and Applied Sciences, v. 21, no. 1, 15-22, 2015b. https://doi.org/10.4314/njbas.v23i1.3

License information: This is an open-access article distributed under the terms of the Creative Commons Attribution License, which permits unrestricted use, distribution, and reproduction in any medium, provided the original work is properly cited. 